\title{
CHINESE INVOLVEMENT IN VANUATU AND SOLOMON ISLAND FOREIGN POLICY AGAINST THE PAPUA ISSUE
}

\author{
${ }^{1}$ Marinus Mesak A. Yaung, ${ }^{2}$ Yanyan M. Yani, ${ }^{3}$ Windy Dermawan \\ ${ }^{1,2,3}$ International Relations, University of Padjajaran, Bandung, Indonesia \\ ${ }^{1}$ nusyaung@gmail.com, ${ }^{2}$ yan2m@hotmail.com, 3 windy.dermawan@unpad.ac.id
}

\begin{abstract}
The influence of China in the Pacific region increases due to the Belt and Road Initiative (BRI) program that focuses its assistance and soft loans on the development of basic infrastructure and other supporting infrastructure. Increased economic influence has an impact on changes in regional geopolitical maps. China appears to be increasingly dominant in influencing the foreign policy of the region's countries, including China's involvement in controlling Vanuatu and Solomon Island's foreign policy. At present, the issue of Papua is on the main agenda of Vanuatu and Solomon Island's foreign policy. Significant funds are needed to finance the process of advocating for the issue of Papua in the Pacific region and the international community. One source of funding comes from Chinese aid. This article will review China's position as a source of the financing for the Papuan separatist movement based in Vanuatu and Solomon Islands, by using a power approach and economic diplomacy.
\end{abstract}

Keywords: China, Belt, and Road Initiative, economic, diplomacy, Power, Vanuatu, Solomon Island, and Internationalization of Papuan Issues

DOI: 10.33541/sp.v20i2.1931

Sociae Polites : Majalah Ilmiah Sosial Politik

Faculty of Social and Political Science, Universitas Kristen Indonesia

ISSN 1410-3745 print/ ISSN 2620-4975 online

Volume 21, Number 1 (January - June 2020)

Pages 96-111 


\section{Introduction}

\subsection{Background}

The South Pacific Region is a strategic area, which is termed the " Pacific Theater.' This term is to show that all islands along with the Pacific Ocean, which is flanked by the Asian continent in the Eastern Hemisphere, the American continent in the Western Hemisphere, and the Australian continent in the Southern Hemisphere, resembling a 'Theater,' are ' foreign ' forces (either superpowers, medium and small powers) who are always paying attention to developments in the region. Besides that, this area, also known as Western Lake, is an unstable region of the political and economic system. Geopolitical developments in this region often give rise to regional instability events. Starting from the resistance movement of the Nagriamel armed group in Vanuatu, who rejected Vanuatu's independence in 1980, then the military coups in Fiji in 1987 and 2006, PNG armed clashes with armed separatist groups Bougainville which lasted for a decade since 1988. The emergence of a political crisis in Vanuatu in 1988 and the assassination of a Kanak leader in New Caledonia in 1989 are a series of extraordinary events that have constructed the political and security dynamics of the South Pacific region.

Despite these events, other internal problems such as ethnic group disputes and low-level intensity conflict in Solomon, Vanuatu, PNG, New Caledonia, continue to burn. The problem of weak law enforcement and social order in almost all countries, high levels of transnational crime, such as money laundering, smuggling, and trafficking in persons, drug trafficking and small arms, theft of marine wealth, etc. continue to occur. Normally, the South Pacific status as the arc of instability makes most of the developed countries, including Indonesia, maintain diplomatic distance with the countries in the region. To carry out economic cooperation and invest capital in this region, not all business actors and capital owners dare to do so. The South Pacific is not a potential and prospective economic market. Most of the population has an income below the national average. The purchasing power of people is deficient. But China has a different view of the region. President Xi Jinping encouraged Chinese companies to conduct massive trade and investment in the area.

Chinese penetration increased after Australia and New Zealand isolated Fiji in the aftermath of the 2006 military coup. Fiji's military government Frank Bainimarama responded to this isolation with its foreign policy. Look to The North by drawing closer to China. Australian and New Zealand foreign policy which froze Fiji's membership in the Pacific

Island Forum (PIF) opened up opportunities for China to get closer to the Melanesian Spearhead Group (MSG), which is a 'competitor' for PIF. China later became the leading supporter of the MSG. It will build an MSG secretariat office in Port Villa, Vanuatu, in 2006. Since 2006, China's influence in the South Pacific began to increase. Evidence of China's growing presence with the BRI program package financed by the Asian Infrastructure Investment Bank (AIIB) is starting to be enjoyed by countries in the region. In the end, it raises a variety of guesses, both positive and negative. Is it true that China has the capability and high intention to become a new hegemony in the South Pacific? The question of speculation seems reasonable, given that China has established relations with countries in the region since the Cold War era through various financial and trade assistance. China's presence and interaction in the South Pacific not 
only involves developing countries but also with the countries of the old hegemony in the region.

New Zealand Prime Minister Robert Muldoon said to Deng Xiaoping at the time that, 'any support China could give to the island states of the [Pacific] Forum whether political or economic would help maintain political stability in the South Pacific' (Brady, 2008: 11). Next was Australia, the first Western country at that time under the leadership of Prime Minister Gough Whitlam, who established diplomatic relations with the Beijing 'communist regime', so Prime Minister Whitlam was called the father of Australia-China Relations (McDonnell, 2014). During the Cold War, New Zealand and China established intensive and mutually beneficial diplomatic relations.

Over time, China's attention to the South Pacific has increased and intensified. This is indicated by the increase in Chinese aid and soft loans to countries that establish diplomatic relations with them. China is listed as the third-ranked donor after Australia and the US. The 'Bamboo Curtain' country also offers various financial assistance packages aimed at strengthening trade, building infrastructure, enhancing the capacity of government and the military, and developing natural resources (Shie, 2007: 309). Nonbinding economic assistance with soft conditions (Yang 2009: 139) is a major attraction for South Pacific countries, which generally have below-average national income.

This situation makes China transformed into a 'new banker' in the South Pacific region. Fifita and Hanson explain the description of China as a new financial source through the title of his article China in the Pacific: The New Banker in Town (April, 2011). A report was explaining that China will become the main donor of the Pacific now and in the future.

In addition to economic aid instruments, the intensity of Chinese attendance was also supported by cultural diplomacy, such as the establishment of a law school at the University of the South Pacific in Suva (Fiji's capital), student exchanges, and teaching Mandarin on local television stations. The leaders of the Pacific countries welcomed soft Chinese diplomacy. The status of China as a fellow developing country and positioning of cooperation with the Pacific within the framework of south-south cooperation much helped the acceptance of its presence in the region. Beijing has long been the first foreign capital to be visited by newly installed Pacific leaders. Visits of Fijian, Vanuatu, PNG, Samoa, Federated States of Micronesia, Tonga, Kiribati, and Solomon Islands leaders shown that these leaders put more hope in China than in the US, Australia and New Zealand (Henderson \& Reilly 2003: 95). The arrival of President XI Jinping at the APEC meeting in November 2018 in Port Moresby, and the renewal of the BRI program agreement with the Pacific countries, further gave China an ample opportunity to dominate the South Pacific.

\subsection{Research Questions}

Why is China involved in the foreign policy of Vanuatu and Solomon Island in resolving the internationalization of the Papua issue in the South Pacific?

\subsection{Research Objectives and Purposes}

This study aims to present an important challenge for the Government of Indonesia in resolving the issue of internationalization of the Papua issue in the South Pacific. Challenges of diplomacy are not only of Vanuatu and Solomon Islands, but also, 
there is China into a new hegemony force in the South Pacific and participated involving supporting the Vanuatu and Solomon Island advocacy process on the Papua issue.

Research has theoretical and practical purposes. Theoretical purposes, where this research will be one of the theoretical references in the study of international relations that money is one of the diplomacy instruments that is very dominant and decisive. Money diplomacy is an instrument ideally able to influence the foreign policy of other countries.

While practical purposes, research is hoped will be a matter of data secondary to the research purposes of the researchers who involved in the regional and international political issues. Besides, it is also the result of the research that is to be used as material studies of international relations students in various universities in Indonesia.

\section{Literature Review}

\subsection{The Concept of Sovereignty and Power}

This article uses a theoretical framework or concept based on three concepts of analysis - namely, the idea of sovereignty, power, and economic diplomacy. Morgenthau and Thompson, in their book Politics Among Nations, The Struggle for Power and Peace (6th ed.) (1997: 331,332), say that sovereignty also has meaning as independence, equality, and integrity (independence, equality, and unanimity). The meaning of independence means that all countries are free to regulate the affairs of their country, both internally and externally, as long as these affairs do not exceed applicable international law.

The meaning of equality can be seen in Article 2 of the Charter of the United Nations (UN), which states that "the organization is based on the principle of sovereign equality of all its members." While the meaning of wholeness in question is a function of the legislature of all countries is the same, regardless of the size, population, and strength of these countries.

While the concept of power itself is the ultimate goal of politics, which is absolute, and all countries will prioritize it as the primary goal and target to be obtained. According to Baldwin, there are four ways to apply a country's power to increase its influence or for the hegemony of a state or other region. The four modes, namely through a symbolic approach, economical approach, military approach, and diplomatic approach (Baldwin, 2013: 275). China is increasing its influence in the South Pacific by applying its powers in the economy and strategic symbols needed by the Pacific. Furthermore, Morgenthau conveyed his thesis that three types of power are fought for in the international political order. The three types of power are the status quo policy, imperialism, and prestige (Pham, 2008: 257,258). The kind of power that can help analyze China's interests in its involvement in supporting the position of Vanuatu and Solomon Island on the issue of Papua is imperialism and maintaining the One China Policy status quo policy and its sovereignty over the South China Sea.

\subsection{Economic Diplomacy}

Besides, to analyze and describe the goals and interests of China who are very interested in the South Pacific region to open up massive trade and investment relations in the "Pacific Theater" region, the economic diplomacy approach will be a theoretical 
and analytical instrument in writing this article. According to Milner and Tingley, in their book Geopolitics of Foreign Aid (2013), economic diplomacy will always be the dominant instrument with two main objectives in international politics. The first objective, economic diplomacy, will be an instrument of trade and interaction between one country and another. The second objective, economic diplomacy, will become a political instrument to achieve the power and prestige of a state. Where economic diplomacy has direct implications for the geopolitical order in international relations.

Referring to Milner and Tingley's theoretical concept of economic diplomacy, it will be able to answer public questions about why China is so massive and responsive to trade and invest its capital in the South Pacific countries. Countries that are economically and politically, not prospective trade markets and have political and security instability. In the logic of economic and trade activities, all export and import activities must bring foreign exchange to the country. It is more profitable for China to invest capital and assets in the Southeast Asian or South Asian markets, compared to investing in the South Pacific. Where the population of this region, the total population is the same as the population of the city of 'Corona Virus' Wuhan, Hubei Province, China. So with economic logic, it is difficult to answer these public questions. But third, using political philosophy, China's foreign policy to the Pacific can easily be found in its goals and interests.

Economic diplomacy for political purposes is a form of international trade politics, in the sense that trade relations and investment in any way with external parties, such as the BRI China program in the form of grants and soft loans, will always prioritize national interests. Therefore, foreign trade will always be placed under control by the state. The political perspective of international trade is the construction of thought of the followers of Mercantilism. Mercantilist thinkers claim that business is the dominant instrument that can be used by the state to accumulate wealth and capital. With great wealth and capital, a country will have power and achievements in other countries. To accumulate wealth and capital, thinkers of Mercantilism justify the expansionist, manipulation, and exploitation methods in international trade (Umar Suryadi Bakri, 2015: 114). The expansionist character of business, manipulation, and exploitation is reflected clearly in the BRI China assistance package.

Therefore, the strength of the old hegemony in the South Pacific has reminded many times that its traditional partners will be debt-trap diplomacy in China. South Pacific countries are reminded of the threat of losing state sovereignty and also losing the country's strategic assets. As the state of Sri Lanka, the loss of the Hambantota port is very strategic and has economic value for the country's foreign exchange. The same event has the potential to occur in the South Pacific. The nation of Vanuatu could lose the port of Luganville on the island of Espiritu Santo. The State of Solomon Islands has the potential to lose the port of Tulagi, the seaport that Japan and the Allies had used in the Pacific war. But the underdevelopment of development and extreme poverty due to the lack of infrastructure, made the South Pacific welcome with open arms of Chinese aid and soft loans. Even Solomon Island must break diplomatic relations with Taiwan, which has been built for 36 years to get Chinese development and investment assistance.

Over time, China will emerge as a new hegemony in the South Pacific. The issue of Papua, which is the subject of political diplomacy in Vanuatu and Solomon Island, will attract Chinese involvement in it. The entry of Benny Wenda, chairman of ULMWP, in the Vanuatu delegation to the PIF meeting in August 2019 in Tuvalu and agreement with 16 Pacific countries in the forum, to pressure Indonesia on Papua, is a strong 
indication of China's strong support in the process of internationalization of the Papua issue.

\section{Research Method}

This study uses qualitative research methods by focusing on data collection and analysis. Research Qualitative often depends on the inductive conclusion (Boejoe, 2009: 15). Qualitative research methods have several types, one of which is descriptiveinterpretation type. The author uses the technique because it is the first step of research, namely by carefully collecting data and observing the phenomenon, then interpreting and making conclusions to answer the problem of research (Lamont, 2005: 30).

Qualitative approach is used as research method selection with the purpose so that the public knows that behind the Chinese soft aid and loans through the Belt and Road Initiative (BRI) program, the country receives loans that are not free of the interests of China national. In the course of BRI's program, China has a hidden agenda that will arise at a moment when the aid and loans receiving state are not able to pay back the loan. To complement this research data, the authors look for and collect primary data from the writing articles of the political observers outside China. Primary data is combined with the secondary data of the media - the mainstream media in the Pacific South publishes the results of their interviews with the elite politics of Vanuatu, the Solomon Islands and China, as well as some of the data from a relevant file of the Ministry of Foreign Affairs, magazines, websites, publications government, and research.

\section{Analysis and Discussion}

\subsection{China's Involvement In The Internationalization Of The Papua Issue In The South Pacific}

The principle of reciprocity in international law explains that all actions taken by one country against another country, both positive and negative, can be rewarded in kind (Wagiman Mandagi, 2016: 50). The foreign policy of Vanuatu and Solomon Islands, which supports the "One China Policy" foreign policy, can be reciprocated by China by supporting Vanuatu and Solomon Island's foreign policy towards the Papua issue. The position of foreign policy like this can be justified. However, it has not yet seen the Chinese political views on the internationalization of the Papua issue in the Melanesian bloc directly. However, indications of Chinese involvement can be read when the perspective of foreign aid narrated by Helen V. Milner and Dustin Tingley in their book entitled Geopolitics of Foreign Aid (2013), is used as the basis for analysis and study of China's national interests.

Milner and Tingley explain that foreign aid has been used since World War I when rich countries provided goods, services, and funds as instruments to interact with other countries. In the cold war era, foreign aid became a political and diplomatic instrument for donor countries to help control the governmental policies of creditor countries. Foreign aid will always be loaded with political and security interests to build hegemony and form a geopolitical map of the United States and the Soviet Union (Milner \& Tingley, 2013: 3). Foreign aid will always have implications for regional and international geopolitical developments. 
Thus increasing Chinese foreign aid in the South Pacific will be perceived by old traditional forces in the South Pacific, such as the United States, Australia, New Zealand, Japan, France, Britain, and the European Union as a threat to their interests. Besides that, as time goes by, when the Melanesian bloc countries are already in the influence of China, of course, the importance of China will also overlap with the issue of Papua. At present, China is listed as the third-largest donor after Australia and the US in the South Pacific. Through its ambitious program of road and belt initiatives, which are supported by funding of the Asia Infrastructure Investment Bank (AIIB), China offers a variety of financial and investment assistance packages. With the main objective to strengthen trade, build basic infrastructure and supporting infrastructure, improve the ability of government and military, and develop natural resources (Shie, 2007: 309). Economic assistance and financial loans on soft and nonbinding terms (Yang, 2009: 139) are the main attraction for South Pacific countries, which generally have below-average national income.

The development of this situation will make China transform into a "new banker" in the region, the South Pacific, as explored in the writings of Fifita and Hanson (2011) under the title China in the Pacific: The New Banker in Town. In addition to economic aid instruments, the intensity of Chinese attendance is also supported by cultural diplomacy, such as the establishment of a law school at the University of the South Pacific in Suva, Fiji, student exchanges, and Mandarin teaching on local television stations in PNG, Fiji, Solomon Island, and Vanuatu. The leaders of the Pacific countries welcome China's economic and financial diplomacy. Even China's status as a fellow developing country has dramatically helped its acceptance in this region. With the concept of cooperation in the south-south, China is increasing its influence in this region.

South Pacific relations with Beijing then become increasingly close and harmonious. The capital city of Beijing is the first foreign capital to be visited by newly installed Pacific leaders. The visit of the leaders of Fiji, Vanuatu, Solomon Island, PNG, Samoa, the Federated States of Micronesia, Tonga and Kiribati shows that these leaders have more hope in China than in the US, Australia and New Zealand (Henderson \& Reilly 2003: 95). The arrival of President XI Jinping at the APEC Summit in Port Moresby on November 15, 2018, earlier than all world leaders and directly visited Chinese-funded infrastructure projects, received an extraordinary reception. President Xi Jinping then gathered all the South Pacific countries on November 16, 2018, and committed to increasing aid and loans worth 5.8 billion US dollars to all Pacific countries. And an investment of US \$ 3.5 billion to PNG for the construction of road infrastructure from Port Moresby to the entire interior (news.detik.com, 16 November 2018). This agreement allows China to access more freely the South Pacific region.

Although China provides soft conditions and easy access in its negotiation process and trade agreements, this fact does not make the South Pacific countries free from the pressure of Chinese interests. Theoretically, foreign aid will always have a political and economic motivation, according to Alan Rix (1993: 18-19) that political motives in granting foreign aid focus on the goal of improving the image of donor countries. With a pattern of soft foreign aid and loans under the shell of south-south cooperation, China wants to redefine its country's image as developing countries. A country that wants to see economic and trade cooperation based on the principle of the non-zero-sum game, not based on the law of the zero-sum game carried out by western countries so far. 
Furthermore, the economic motives behind foreign aid, according to Yanuar Ikbar (2007: 191) that economic incentives are the most rational justification for granting foreign assistance. Because no country in the world can afford to meet its own economic needs. Therefore, even though China is one of the countries with the strongest economic growth in the world, with the growth of around $7 \%$ per year, it is still to meet the needs of the country's manufacturing and energy industries, China is very dependent on imports of raw materials from other Asian and Pacific countries. But economic and political motives will always be a package of a country's foreign policy, like a currency that has two sides and cannot be separated from one another.

When the United States in the era of President Kennedy 1960-1963, helped the recovery of the Indonesian economy, the political motives that dominated the aid and encouraged the United States to support President Soekarno's position on the issue of Papua. China is developing the same pattern at this time in the South Pacific countries. One China Policy's foreign policy is an absolute standard that cannot be negotiated by any country that wants to trade with China. China's official position is that its jurisdiction includes Macau, Hong Kong, Taiwan, Tibet, and Xinjiang, which cannot be questioned and debated. Around 160 countries in the world support this One-China policy. Without this support, China will not allow the establishment of trade or diplomatic relations with it (Milhiet, 2017: 4,5).

China also treats the same foreign policy standards to Vanuatu and Solomon Islands. If you want to increase bilateral relations with China and get financial and investment assistance, you must first leave diplomatic recognition of Taiwan (Antaranews.com, 9 October 2019). What happened next, Solomon Island, which had 36 years of diplomatic relations with Taiwan, had to shift diplomatic recognition from Taiwan to China in September 2019. This diplomatic action was to fulfill the criteria of the Belt and Road Initiative (BRI) program that promised development assistance of 500 million US dollars. Vanuatu is also the same quarter of money with Solomon Island. Vanuatu's anti-colonialist and imperialist foreign policy makes this country always sympathize and support Taiwan's position but has never dared to give diplomatic recognition to Taiwan.

The characteristics of South Pacific countries that have infrastructure gaps, poverty and underdeveloped in development, and have low average national opinions, make them highly dependent on national income from foreign aid. As a result, they are sometimes inconsistent and quickly change their national perceptions of regional or international issues. Author Oliver Bollough in his article titled This Tiny Pacific Island Nation Just Gave Russia a Big Bruise (2014), has defined the character of their foreign policy. The South Pacific countries represented by Nauru, Tuvalu, and Vanuatu tend to represent the character of diplomacy without credibility and dignity. According to Bollough that 'It might be unfair to call Nauru, Tuvalu, and Vanuatu diplomatic prostitutes, but they have tended to hook up with anyone who'll pay them ' (Bollough, 2014: 1). In other words, Bollough states that the foreign policy position of the South Pacific countries is primarily determined by who the actors are willing to pay for them. Then they will cooperate with the actor.

Indeed, Bollough's thesis, which lays out the pattern of foreign diplomacy in South Pacific countries as diplomatic prostitution, seems extreme and highly speculative. But the reality that occurs in the field supports the bollough thesis about the character of their diplomacy. For example, in the case of Vanuatu's diplomatic support, Solomon Island and the MSG forum on the issue of Papua, read very loaded with economic 
interests. The Indonesian government, as a member of the forum association since 2015, is forced to help finance the operations of the troubled MSG secretariat office in Port Villa Vanuatu. The MSG secretary office, which was built by China, almost stopped operating because full member states defaulted on their financial obligations. The political impact, MSG director-general in 2016 Amena Yauvoli, stated openly that the MSG was not a place to discuss the issue of Papua. The issue of Papuan human rights violations and the political status of Papua was not on the agenda of the MSG (Suara Papua, 28 July 2018). The MSG director's statement suggests that the MSG supports Indonesia's position on the Papua issue.

From the narrative of the politicization of the Papua issue in the MSG, it was confirmed clearly that when economic and financial diplomacy was carried out by Indonesia, the geopolitical map in the Melanesian block would change and raising support for Indonesia's position on Papua could be achieved. The power of money as a diplomatic instrument can increase significant political influence and be able to change the geopolitics of the South Pacific region. Tiongkok was currently playing diplomacy in the Yuan currency to increase its power in the Melanesian bloc and the South Pacific widely. The State of Vanuatu and Solomon Islands received significant financial assistance and loans and infrastructure investment.

\subsection{China Funds Vanuatu's Foreign Policy}

China's diplomatic relations with Vanuatu have been established since 1982. a year after Vanuatu gained independence from Britain and France. Vanuatu, since independence on 30 July 1980, has facilitated Papuan nationalist groups with its separatist agenda. This political policy was carried out by PM Walter Lini. Where PM Lini invited 19 independent Papuan activists from the Netherlands, Australia, and PNG to settle in Port Villa. The activities of the Free Papua Movement, which were mostly members of the band group of Black Brothers, were asked to assist the PM Lini campaign in the first Vanuatu election in 1983. Lini's political commitment to encourage decolonization in West Papua was strongly influenced by the Melanesian Way's understanding of an anti-colonialism spirit. Over time, Vanuatu later became the main political base of the Free Papua Organization (OPM). The OPM representative office was first opened in the capital city of Port Villa, Vanuatu in 2003, and OPM diplomat John Otto Ondawame led the office as the center of Papua's international campaign. Since then, the issue of Papua has been the main topic in Vanuatu's foreign policy formulation.

The Vanuatu government was spending a large enough amount to finance the Papuan issue campaign. Funds to advocate for the Papua issue were sourced from foreign aid funds totaling the US \$400 million. China accounted for half of the total foreign debt. According to the Sydney Morning Herald report titled China's eyes, Vanuatu military base in plan with global ramifications written by David Wroe said the amount of Chinese aid reached 220 million US dollars (Wroe, 9 April 2018). The financial contribution was to finance the construction of the port of Luganville, the official residence of Prime Minister Charlot Salwai, renovate the office of the Prime Minister and other Government Offices and finance the political campaign of PM Salwai.

The political position of PM Salwai himself in the issue of Papua was one of the leaders in the Melanesian bloc who supported the massive and consistent internationalization of the Papua issue. Together with PM Sogavare in Solomon Island, 
both of them advocated the issue of Papua from the MSG to the PIF community and openly attacked Indonesia about the issue of Papua at the UN General Assembly session. Routinely since 2016, PM Salwai has continued to voice the concern of Papua at the United Nations. But they did not dare to express political support for the Taiwan issue in the same forum. A character of its foreign policy, which has lost its credibility and integrity. And winning was logical because it has already benefited politically and economically from its political commitment with China.

So strong is the domination and control of China over Vanuatu's foreign policy, which naturally raises speculative assumptions that China is involved in financing the internationalization of the Papua issue in the South Pacific. To finance the issue of Papua in the Pacific and to the broader international community, significant funds are needed. ULMWP itself cannot afford its diplomatic trips in the Pacific, and that is why Indonesia can dominate the issue of Papua in the MSG forum. The State of Vanuatu itself is similar. It does not have sufficient funds to prosper the people. According to the International Monetary Fund report, Vanuatu's nominal GDP is only 1.27 billion US dollars. Approximately only $0.1 \%$ of Indonesia's GDP of 1.29 trillion US dollars (Tabloid Diplomacy, February 27, 2015). Because of this, Vanuatu is unlikely to incur political costs from its GDP to finance the internationalization of the Papua issue.

Several elite members of the Vanuatu Parliament, the main elite of the Vanuatu party, and the Prime Minister and his ministers, received funding compensation from the results of the rent-out construction of the Luganville port project on the island of Espiritu Santo and the construction of Rainbow City in the isle of Efata. The gratuity fund was partly given to the Vanuatu Foreign Ministry's Task Force, which carried out the amendment to the Wantok Blom Yumi Law on the Papua problem. The funds were also given to Lora Lini as the Special Envoy of Vanuatu, whose role was to lobby and advocate the issue of Papua to the international community outside the Melanesian bloc. Lora's diplomat is the son of Walter Lini and founder of the Free West Papua Association of Vanuatu, which has a major work program for Papuan decolonization (Godwin Ligo, Dailypost.vu, 25 August 2018). It is common knowledge in Vanuatu that the practice of corruption, bribery, and gratification among the elite always takes place behind international cooperation agreements with China and with other creditors.

China is involved in financing the internationalization of the Papua issue in Vanuatu, not something new in the eyes of the people of Vanuatu. Previously China had been engaged diplomatically supporting the Democratic Republic of East Timor in the UN Security Council and involving Mari Alkatiri and Jose Ramos Horta in its delegation. China also finances weapons purchases for the Fretellin group through the head of East Timor's representative in Vanuatu, Abilio Araujo, who is also a businessman (CAVR Report of Timor Leste, Chega, 2017: 755). If China, which opened official diplomatic relations with Vanuatu in 1982 and 1989, established its large embassy in Port Villa, has been involved in funding the Fretellin group, then it is a necessity that China is also engaged in financing Vanuatu's foreign policy in advocating for the Papua issue. Likewise, the dominant role of China behind Solomon Island's foreign policy towards the issue of Papua.

\subsection{China Funds Solomon Island Foreign Policy}

The success of ULMWP diplomacy to the status of observer at the 2015 MSG was a diplomatic success of Papuan nationalists without solid financial capital. The 
political support of Vanuatu and Solomon Islands which makes the issue of Papua on the MSG and is the main topic of regional discourse. Without the support of these two countries, the internationalization of the Papua issue is only the critical voices of regional civil society that are not too serious for Indonesia's foreign policy. But when there is a country like the Solomon Islands that voices the issue of Papua, it is something that seriously threatens Indonesia's sovereignty over Papua. Because of official diplomatic support from countries such as the Solomon Islands and Vanuatu for the ULMWP, it will strengthen the political entity of these Papuan nationalists in the eyes of international law.

Indeed, a country's national interests will be the last judge to decide on a country's diplomatic support. The Government of the United Kingdom, where the capital of London has become the main base of the Benny Wenda campaign and its Free West Papua Campaign in Europe today, does not dare to provide diplomatic support for ULMWP. Even though the official office of the OPM was opened in the city of Oxford in 2013. The British Parliament had also formed the International Parliamentarians for West Papua (IPWP) on October 15, 2008. Its members come from the Conservative, Labor and Green Party and are scattered in the House of Commons (DPR) and House of Lord (Upper House). Even in the composition of members of the British Parliament, a Papuan caucus has been formed called the British All-Party Parliamentary Group for West Papua and chaired by Andrew Smith, who is from the Labor Party.

The development of the internationalization of the issue of Papua in the UK like this has not yet made the UK issue an official policy to support the existence of ULMWP. In the UK, there is a consensus that official support from Parliament and the Government on a regional or international issue must go through a petition asking for public opinion. The British government will take the position to discuss the issue if a minimum of 10,000 British citizens signs the petition. Parliament, too, if the petition is signed by a minimum of 100,000 people of the British people, Parliament will make the issue as a debate agenda. In 2015, a petition entitled Pressure Indonesia to bold a referendum on selfdetermination for West Papua was initiated by British human rights activist Adam Perry and several nongovernmental organizations such as the UK Tapol NGO, Survival NGO, UK Global Justice NGO. The petition went on for a year, and at the end of October 2016, the petition was only signed by 309 people (Rusdiarti \& Pamungkas, 2017: 197,198). An insignificant number of supporters.

Over time, the country's official diplomatic support for Papuan nationalist groups is only from Vanuatu and Solomon Islands. Both of their favor can bring the issue of Papua into the main topic of discourse outside the Melanesian bloc. The issue of Papua can be discussed in the Pacific island forum, which consists of 18 countries. Prime Minister Sogavare of Solomon Islands as the dominant mediator advocating the Papua issue in the Pacific forum. Establish PCWP as a mount for the politicization of the Papua issue to garner diplomatic support from 18 Pacific countries. Through the PCWP agency, Sogavare is quite successful in advocating the issue of Papua in the Pacific region. Sogavare's campaign to seek political support and diplomacy on the issue of Papua outside the Melanesian bloc, cannot be separated from the financial support of Chinese entrepreneurs. Logically, if China had ever been involved in financing Fretellin's activities in Vanuatu, surely China has the potential to repeat the same actions on Solomon Island as long as the Solomon Island Government's political stance does not harm its interests. 
Funding support for the political activities of Sogavare and the Solomon Islands political elite was carried out by the Chinese company Sam Enterprise Group, a StateOwned Enterprise (BUMN) of the Chinese Government. It is common knowledge on Solomon Island that the company is funding the campaign of Sogavare and several members of Parliament. The company also prepares and facilitates all holiday trips to Singapore and Beijing for the political elite and their families. Compensation due to the convenience of this Chinese SOE gains access and permission to contract Tulagi Island, a former Allied Military base and Japan during World War II, to build its economic and security investment on Solomon Island. Prime Minister Sogavare's government allowed China to lease the island for 75 years (Jubi.co.id, 21 October 2019). The Tulagi Island takeover agreement was made on September 22, 2019, or one week after PM Sogavare severed diplomatic relations with Taiwan and transferred diplomatic support to China.

PM Sogavare's foreign policy to open diplomatic relations with China cannot be separated from the commitment of standardized development and investment cooperation with China. Although Chinese aid and soft loans do not seem so tricky, this economic and trade agreement cannot be separated from political and security interests. Countries that submit proposals for inclusion in the Belt and Road Initiative program must support the One China Policy developed by China. Therefore, PM Sogavare, in the fourth period of his leadership, without the need for consultation and outreach with the people of Solomon Islands, took foreign policy by giving diplomatic recognition to China. The diplomatic transition process went so smoothly and quickly because the financial diplomacy promised by China to the government and the political elite in an extensive Parliament became its dominant factor, where the Solomon Island Government promised aid packages worth 500 million US dollars. And assistance for the campaign costs of PM Sogavare and members of Parliament who support the transition of diplomatic relations amounts to 220.000 US dollars (Lowyinstitute, 23 January 2020). This gratuity fund is often used by PM Sogavare to finance his campaign to advocate for the issue of Papua in the South Pacific region.

A significant amount of funds is indeed needed to finance the internationalization of the Papua issue outside the Melanesian bloc community. It is impossible to finance the Papua issue from Solomon Island and Vanuatu state opinions. Because both of these by the United Nations Development Program (UNDP) are included in the list of Least Developed Countries (LDCs) or the list of underdeveloped developing countries. The criteria for a country categorized in the LDCs list are, first, the level of poverty (poverty). Countries whose Gross National Income Opinion lacks \$ 1,035 a day. Second, the Human Development Index. These criteria are based on indicators of health, nutrition, education, and literacy, or literacy levels. Starting in 2015, the United Nations established the country in the category of a

developing country that is underdeveloped if its human development index is below 60 percent. Third, the index of economic vulnerability. This criterion is based on the instability of agricultural production, the instability of exports of goods and services, and the percentage of people displaced by natural disasters or other social disasters such as war or riots (Satuharapan.com, 17 April 2018). The State of the Solomon Islands and Vanuatu meet all three of these criteria. So it's too naive to think that these two countries are financing internationalization of the Papua issue from their own national income money.

China, as a country that is currently involved massively financing infrastructure development on Solomon Island and Vanuatu, is undoubtedly a source of funding also 
from the political journey of PM Sogavare and PM Charlot Salwai advocating the issue of Papua in Melanesia and to the broader civic community. High diplomacy costs are needed to garner South Pacific political support for the Papua issue. Because almost evenly, the character of prostitute diplomacy hypothesized by Bollough is displayed clearly in the profiling diplomacy of the countries of the South Pacific region on regional and international issues. The national perceptions of these regional countries on regional and international issues are often inconsistent and unstable.

Before China's influence increased in the region, the internationalization of the Papuan issue was only a diplomatic discourse and debate in the Melanesian bloc. It is difficult to advocate for it in the Pacific Islands Forum, and it is the main topic on the forum agenda. The main obstacle is. First, the diplomatic relations of the South Pacific countries with the old traditional forces in the region are very powerless or unbalanced. This traditional strength of the Pacific region has always supported Indonesia's position on the issue of Papua. Second, because of the culture of diplomacy in the South Pacific region countries that respond to all the international problems from the perspective of political and economic commodities. More clearly and extreme, the political elite and leaders in this region are a group of thieves and corruptors. Their policies are easily dictated and intervened by foreign investors (Jubi.com, 21 October 2019). Therefore, with significant financial capital, China freely realizes its national interests in the region.

With the emergence of China as a new hegemonic force capable of changing the geopolitical map of the region, South Pacific countries then opened the door to the issue of Papua to the agenda of the Pacific Islands Forum (PIF). At the PIF Summit in the capital city of Funafuti, Tuvalu, from August 13-16, 2019, the forum countries united to support the position of Vanuatu and Solomon Islands on the issue of Papua. Even the Vanuatu delegation bravely included Benny Wenda, chairman of ULMWP, as a member of the commission. Never before had there been considerable and diplomatic severe pressure from the Pacific on

Indonesia over the issue of Papua. According to Meaghan Tobin, in an article titled 'Is Chinese support for the Pacific nations shaping their stance on Indonesia's West Papua?' Published in the South China Morning Post explained that Chinese assistance made Pacific countries increasingly confident in openly criticizing Indonesia's position on the issue of Papua ( Tobin, 2019). The increasing influence of China, which was increasingly significant because it was able to answer the very minimal infrastructure needs in the Pacific countries, has an impact on increasing the courage of the Pacific countries to get out of the pressure of Australian and New Zealand diplomacy.

The latest developments in the South Pacific, Australia, and New Zealand, which have so far taken control of the Papua issue in the Pacific and helped determine the position of Pacific countries on the issue of Papua, have begun to lose power to support Indonesia's position. The two countries experienced a foreign policy dilemma on the Papua issue. Supporting Indonesia's post will further make them lose their influence in the South Pacific. Supporting the verdict of the Pacific island forum, which urged UN intervention in resolving the Papua issue, would make Australia, in particular, violated the Lombok Treaty Agreement with Indonesia in 2006.

In the end, the power of the old hegemony in the South Pacific region will compromise with the foreign policy of the islands of the Pacific on the issue of Papua because that's the opportunity and one of the strategic plans they can do to offset the increasing influence of China in the region. Thus, the issue of Papua, which has only been a political and diplomatic issue of Vanuatu and Solomon Island in the Melanesian 
bloc, has strengthened and expanded into the Pacific region due to the increasing influence of Chinese financial and investment diplomacy. The growing influence of Chinese diplomacy dictated the foreign policy of Vanuatu and Solomon Island because China has become an alternative source of funding besides Australia and New Zealand. An increasing number of foreign loans were increasingly significant and has led to economic and development dependence on China. In other words, like in the 1960s, US President John F. Kennedy made foreign aid through the Marshall Plan program, as a political and security instrument in his international policy, so that made the US involved in solving the problem of Papua between Indonesia and the Netherlands, this history is being recycled by President Xi Jinping through the Belt and Road Initiative program in the South Pacific today.

\section{Conclusion}

In the international political constellation, economic interests will always intersect with political interests and vice versa. Therefore, trade and investment cooperation in the form of a BRI China program package are not free from economic and political interests. There were already political calculations before China expanded the South Pacific region. With foreign aid and loans increased due to the high financial burden on infrastructure development, China has predicted that the South Pacific countries will have difficulty paying their debts. With the condition of defaulting on debt, it will make it easier for China to access and exploit the strategic assets of creditor countries. China will also easily manipulate the Papua issue that was being advocated by Vanuatu and Solomon Islands to pressure Indonesia to give China access to Papua's natural resources.

The need for raw materials for China's manufacturing and technology industries in the future, in addition to political sovereignty over Taiwan and the South China Sea, are the dominant factors that shape China's perception of the South Pacific's strategic position. China has seen the "Pacific Theater" region, which is rich in mineral resources, is the future of China's industry and economy. China's involvement in the internationalization of the Papua issue is due to its interest in accessing mineral resources in Vanuatu, Solomon Islands and Papua. in other words, China's involvement in supporting Vanuatu and Solomon Island's foreign policy in the internationalization of the Papua issue, is not in the interests of Papua and the Melanesian bloc. But for the benefit of industry and China's economic growth in the future. The political issue of Papua is the instrument of China's economic investment in the current South Pacific region. 


\section{BIBLIOGRAPHY}

\section{Books}

Baldwin, David A, ( 2013 ), Power and International Relation in Handbook of International Relations, London: SAGE Publications Ltd.

Boejoe, H. R., ( 2009 ). Analysis in Qualitative Research. First. London: SAGE.

Brady, Anne-Marie, ( 2008 ), "New Zealand-China Relations: Common Points and Differences". New Zealand Journal of Asian Studies.

Ikbar, Yanuar,( 2007 ), Ekonomi Politik Internasional : Implementasi Konsep dan Teori, Bandung : PT. Refika Aditama.

Lamont, Christoper. ( 2005 ). Research Methods in International Relations. First, London: SAGE.

Mandagi, Wagiman Anasthasya Saartje, 2016, Terminologi Hukum Internasional, Sinar Grafika, Jakarta.

Milhiet, Paco, ( 2017 ), China's Ambition in The Pacific : Worldwide Geopolitical Issues, Asia Focus, Vol. 49, Paris : Institut de Relation Internationales et Strategiques

Milner, Helen V, \& Tingley, D.H, ( 2013 ), Geopolitics of Foreign Aid, vol. 1, Cambridge : Edward Elgar Publishing

Morgenthau, Hans J, \& Thompson, Kenneth W,( 1997 ), Politics. Among Nations - The Struggle for Power and Peace, (6 ed.), Singapore: McGraw Hill.

Pham, Peter J, ( 2008 ), What Is in the National Interest? Hans Morgenthau's Realist Vision and American Foreign Policy, American Foreign Policy Interests.

Rix, Alan. ( 1993 ), Japan's Foreign Aid Challenge : Policy Reform and Aid

Leadership, Londong and New York : Routledge

Shie, T.R, (2007 ), Rising Chinese influence in the South Pacific, Asian Survey. Yang, Jian, ( 2009 ), China in the South Pacific : hegemon on the horizon?. Pacific Review.

\section{Articles and Journal}

Bollough, Oliver, https://newrepublic.com/article/117238/tuvalu-bruisesrussiaestablishing-diplomatic-ties-georgia, newrepublic.com, 3 April 2014

Fifita, Mary \& Hanson, Fergus, ( 2011 ), China in The Pacific : The New Banker in Town, Honolulu : Pacific Forum CSIS.

Henderson, John \& Reilly, Benjamin, ( 2003 ), Dragon in Paradise: China's Rising Star in Oceania". The National Interest.

Ligo, Godwin, https://dailypost.vu/news/if-vanuatu-does-not-speak-for-west- papuathen-who/article 4fbe1b69-9724-5ac6-b0d2-b667aac160a9.html, dailypost.vu, 25 August 2018.

Final Report on Truthness and Reconcialian Acceptance ( CAVR ), 19 June 2017, Chega !, Vol. 2, Dili : CAVR - Kompas Gramedia Group.

McDonnell, Stephen, ( 20014 ), "Gough Whitlam: Prime Minister the Father Of Australia-China Relations, Beijing. Dalam http://www.abc.net.au/NEWS/20141022/whitlam-father-of-china- australia- relations-beijinG/5832076. Accessed 25 April 2020. 
Tebai, Bastian, $\quad$ https://suarapapua.com/2018/07/28/dirjen-sekretariat-msgamenayauvoli-msg-bukan-tempat-untuk-bicara-papua-barat/, Suara Papua, 28 July 2018.

Tobin, Meaghan, https://www.scmp.com/weekasia/geopolitics/article/3024136/chinese-support-pacific-nations-shapingtheirstance, scmp.com, 24 August 2019.

Wroe, David, https://www.smh.com.au/politics/federal/china-eyes-vanuatu- militarybase-in-plan-with-global-ramifications-20180409-p4z8j9.html, The Sydney Morning Herald, 9 April 2018 https://www.lowyinstitute.org/theinterpreter/china-has-honiara-onside-hasn-t- yetwon-over-solomon-islands, Lowyinstitute.org, 23 January 2020.

http://www.tabloiddiplomasi.org/hubungan-ekonomi-indonesia-vanuatupenting-dan-strategis/, Tabloid Diplomasi, 27 February 2015 http://www.satuharapan.com/read-detail/read/pbb-umumkan-solomonislandslayak-keluar-dari-daftar-ldcs, Satuharapan.com, 17 March 2018.

https://www.ceicdata.com/en/indicator/vanuatu/forecast-nominal-gdp-per- capita, International Monetary Fund, 1980 - 2024, Ceicdata.com, 9 April 2020.

https://koran.tempo.co/read/internasional/69830/perdana-menteri-solomon- mundur?, Tempo Newspaper, 27 April 2006

https://www.antaranews.com/berita/1104562/china-solomon-teken-kerja - samadalamhubungan-diplomatik-baru, Antaranews.com, 9 October 2019. 